Original Research Paper

\title{
Pembuatan Yogurt Susu Sapi Sebagai Upaya Meningkatkan Nilai Fungsional Susu, Gizi Masyarakat dan Pendapatan Rumah Tangga di Masa Pandemi
}

\author{
Siti Rahmawati Zulaikhah ${ }^{1}$, Arif Harnowo Sidhi ${ }^{1}$ \\ 1 Program Studi Peternakan, Fakultas Sains dan Teknologi, Universitas Nahdlatul Ulama Purwokerto, Jawa \\ Tengah, Indonesia
}

https://doi.org/10.29303/jpmpi.v3i2.924

Sitasi: Zulaikhah, S. R \& Sidhi, A. H. (2021). Pembuatan Yogurt Susu Sapi Sebagai Upaya Meningkatkan Nilai Fungsional Susu, Gizi Masyarakat dan Pendapatan Rumah Tangga di Masa Pandemi. Jurnal Pengabdian Magister Pendidikan IPA, 4(3)

\section{Article history}

Received: 31 Agustus 2021

Revised: 20 September 2021

Accepted: 22 September 2021

*Corresponding Author: Siti Rahmawati Zulaikhah,

Universitas Nahdlatul Ulama

Purwokerto, Jawa Tengah,

Indonesia

Email:

rahmawatidjunaidi0@gmail.com

\section{Pendahuluan}

Produk hewani selain daging dan telur yang sebenarnya mempunyai nilai gizi dan harga terjangkau adalah susu. Susu bisa berasal dari sapi maupun kambing. Menurut Anjarsari (2010) dalam Anindita dan Soyi (2017), komposisi kimia yang terkandung dalam susu diantaranya lemak 3,8\%, protein $3,2 \%$, laktosa $4,7 \%$, abu 0,855 , air $87,25 \%$,serta bahan kering $12,75 \%$. Kelengkapan gizi susu ini mengakibatkan terjadinya permintaaan yang tinggi akan kebutuhan konsumsi susu.

Seperti produk peternakan yang lain, susu juga mempunyai kelemahan yaitu mudah mengalami kerusakan, sehingga memerlukan penanganan yang khusus untuk mempertahankan kualitasnya. Inovasi yang digunakan dalam pengolahan susu agar mempunyai daya simpan lama, meningkatkan nilai fungsional dari susu dan relative disukai konsumen adalah dengan proses fermentasi, salah satu produknya adalah yogurt.

Yogurt mulai dikenal dan digemari oleh semua kalangan, karena rasanya yang khas, segar dan harga terjangkau. Pembuatan yogurt dengan cara memfermentasi susu yang sudah dipasteurisasi menggunakan starter bakteri, kemudian diinkubasi selama beberapa jam sampai didapat produk yang mengental yang disebut yogurt. Agar yogurt diterima oleh konsumen, biasanya diberikan pemanis dan aneka rasa, setelah itu dikemas. 
Menurut Candra Sari, et. al (2020) Fermentasi memiliki hakikat proses metabolisme mikroba untuk menghasilkan produk yang memiliki nilai jual tinggi, seperti asam-asam organik, protein sel tunggal, antibiotika dan biopolimer. Fermentasi pada pembuatan yogurt dari hasil kerja bakteri yang membuat asam laktat yang bermanfaat pada kesehatan usus, misalnya bakteri Lactobacillus bulgaricus dan Streptococus thermopillus.

Masa pandemik ini diperlukan imunitas tubuh yang baik dan pola hidup yang sehat sehingga dapat memutus rantai penyebaran virus corona. Imunitas tubuh dapat ditambah dengan mengkonsumsi makanan yang sehat dan bergizi. Yogurt dapat dijadikan alternatif sebagai makanan yang dapat meningkatkan imunitas tubuh. Pembuatan yogurt skala rumah tangga dapat menjadi peluang usaha selain menyediakan produk yogurt yang terjangkau harganya di masyarakat.

Wilayah RT 04/ RW 05 Kelurahan Sumampir adalah salah satu wilayah di Kota Purwokerto yang terletak disebelah utara berdekatan dengan daerah Baturaden. Wilayah ini sangat berdekatan dengan berbagai Perguruan Tinggi seperti UNSOED, IAIN, UNWIKU, UMP dan perguruan tinggi swasta lainnya dan banyak perumahan yang dihuni oleh pasangan muda yang banyak mempunyai anak usia PAUD.

adalah,

Alasan kami memilih wilayah tersebut

1) Berada dalam wilayah yang padat penduduk

2) Penduduk di wilayah tersebut terdapat berbagai macam mata pencaharian ada yang sebagai guru, pegawai kantor, tukang bangunan, wirausaha kecil-kecilan seperti berjualan kue dan kelontong.

3) Anggota PKK di RT 04/ RW 005 ini adalah Ibuibu rumahtangga sebagian besar mereka menambah penghasilan dengan menjadi pembantu rumah tangga di sekitar wilayah itu atau menjadi buruh cuci pakaian. Mereka sangat perlu diberdayakan khususnya dalam sisi ekonomi, dengan menambah wawasan untuk berwirausaha dalam rangka menambah pendapatan keluarga.

4) Ibu-ibu rumah tangga yang bekerja sebagai pembantu atau serabutan biasanya mereka pulang sekitar setelah ashar atau menjelang magrib, sehingga dari sisi pendidikan mereka tergolong yang wajib diberikan tambahan ilmu dan wawasan untuk menambah pengetahuan tentang gizi keluarga.

Setelah melalui pengamatan kami, ada beberapa hal yang menjadi permasalahan yang tidak hanya terdapat pada lokasi pengabdian (PKM) tetapi juga di masyarakat sekitar, yaitu

a. Banyaknya waktu luang bagi ibu-ibu yang tidak bekerja secara formal.

b. Banyaknya pendatang baik dari kalangan mahasiswa maupun pasangan muda yang mempunyai anak kecil, mereka memerlukan fasilitas konsumsi makanan yang praktis, terjangkau namun sehat, yaitu berupa yogurt.

c. Pengetahuan tentang pentingnya menjaga kesehatan terutama imunitas pada saat pandemik, dengan mengkonsumsi susu.

d. Pengetahuan tentang kewirausahaan.

\section{Metode}

\section{Waktu dan Tempat}

Kegiatan pengabdian ini dilakukan di PKK RT 04 RW 05 Kelurahan Sumampir, Kecamatan Purwokerto Utara. Pelaksanaan kegiatan demonstrasi dan pelatihan pembuatan yogurt pada tanggal 5 dan 6 Agustus 2021.

\section{Alat dan Bahan}

Peralatan yang digunakan antara lain: panci, kompor, toples, pengaduk, saringan, corong. Bahan yang digunakan antara lain: susu sapi segar, starter yogurt dari Yogourmet, gula pasir, perisai makanan.

\section{Metode}

Kegiatan ini menggunakan Metode Kaji Tindak yaitu metode yang dilaksanakan dengan cara:

a) Sosialisasi mengenai pentingnya menjaga imunitas tubuh di saat pandemi dengan mengkonsumsi makanan bergizi yaitu susu.

b) Ceramah tentang pengolahan susu terutama produk fermentasi secara umum dan produk yogurt secara khusus.

c) Demonstrasi kepada khalayak sasaran tempat pelaksana program melakukan kegiatan tentang pembuatan yogurt susu sapi.

d) Ceramah tentang kewirausahaan, untuk menambah penghasilan keluarga.

Beberapa tahapan kegiatan yang dilakukan sebelum melakukan tindakan di atas, yaitu dengan 
mengawali melakukan observasi daerah setempat, melakukan identifikasi potensi dan peluang penciptaan usaha baru.

\section{Hasil dan Pembahasan}

Pengabdian ini dilaksanakan di wilayah RT 04 RW 05 Kelurahan Sumampir Kecamatan Purwokerto Utara, karena kondisi pandemik maka hanya diwakilkan pada sejumlah ibu-ibu PKK saja yang hadir kurang lebih 14 orang.

\section{Pelaksanaan Kegiatan}

Kegiatan PKM ini terdiri atas:

1. Sosialisasi kepada ibu-ibu PKK RT 04 RW 05 Kelurahan Sumampir mengenai pentingnya menjaga imunitas tubuh di saat pandemik dengan mengkonsumsi makanan bergizi yaitu susu. Setelah itu mensosialisasikan pengolahan susu yang tinggi nilai fungsionalnya berupa yogurt. Sosialisasi ini dilakukan pada tanggal 5 Agustus 2021 saat pertemuan RT.

2. Saat sosialisasi tersebut ibu-ibu PKK sebelumnya diberikan kuisioner tentang pengetahuan mengenai yogurt dan manfaatnya.

3. Melakukan demonstrasi pembuatan yogurt dari susu sapi pada saat pertemuan PKK di RT tersebut. Demonstrasi ini juga dilakukan pada tanggal 5 Agustus 2021 dan berlanjut sehari setelah pertemuan atau tanggal 6 Agustus 2021, karena dalam pembuatan yogurt membutuhkan waktu untuk inkubasi.

4. Melakukan pemantauan terhadap respon ibu-ibu PKK tentang sosialisasi pembuatan yogurt susu sapi dengan membagikan kuisioner lagi.

Berdasarkan hasil kuisioner di awal sebelum sosialisasi tentang manfaat yogurt, ternyata hampir 43\% dari ibu-ibu belum banyak mengetahui tentang manfaat yogurt, sekitar $50 \%$ sudah mengenal yogurt namun jarang mengkonsumsi yogurt karena alasan harga yang mahal, dan $7 \%$ dari ibu-ibu tidak menyukai yogurt yang mempunyai rasa khas asam.

Kegiatan pengabdian masyarakat (PKM) mengenai pembuatan yogurt ini mendapatkan respon yang positif dari ibu-ibu PKK di RT tersebut. Mereka sangat tertarik dan setuju diberikan pengetahuan tentang cara pembuatan yogurt dan membutuhkan informasi mengenai manfaat dari mengkonsumsi yogurt ini serta keinginan untuk wirausaha dalam rangka meningkatkan penghasilan keluarga.
Kondisi antusiasnya ibu-ibu saat diberikan penjelasan mengenai kewirausahaan ini sejalan dengan pendapat Mahrus et al. (2021) yang menyatakan bahwa dengan adanya krisis ekonomi sebagai dampak dari pandemik Covid-19, pengetahuan tentang kewirausahaan sangat berkembang baik dilakukan dalam pendidikan formal maupun pelatihan-pelatihan.

Setelah dilakukan sosialisasi mengenai pentingnya meningkatkan imun di masa pandemik, dan manfaat yogurt bagi kesehatan, agar ibu-ibu lebih jelas mengenai yogurt maka dilakukan demonstrasi pembuatan yogurt mulai dari awal sampai pengemasan. Ibu-ibu juga diberikan brosur mengenai cara pembuatan yogurt, untuk dipelajari dan dipraktekkan sendiri di rumah.

Pembuatan yogurt pada pengabdian ini mengacu pada pendapat Wahyuningtyas et. al. (2017) dengan modifikasi sebagai berikut:

1. Mempasteurisasi susu segar agar terhindar dari kontaminasi mikroba pathogen.

2. Mendinginkan susu pada suhu $40-45^{\circ} \mathrm{C}$.

3. Memasukkan bibit yogurt sebanyak $5 \%$ dan mengaduknya sampai merata

4. Menginkubasi susu selama 5-6 jam pada suhu inkubator $40-45^{\circ} \mathrm{C}$ dan 12 jam pada suhu ruang.

5. Produk hasil berupa yogurt kemudian disaring.

6. Menambahkan pemanis atau perasa sesuai selera.

7. Mengemas yogurt.

Kendala saat pengabdian ini adalah sulitnya menentukan hari pelaksanaan, karena pertemuan PKK RT hanya dilakukan sebulan sekali, dan saat itu masih dalam kondisi pandemik, dimana pertemuan dengan banyak orang masih dilarang. Kendala ini dapat diatasi dengan menunggu waktu yang tepat dan ijin yang diberikan dari pihak RT serta kesediaan dari ibu-ibu untuk mewakili warga yang lain.

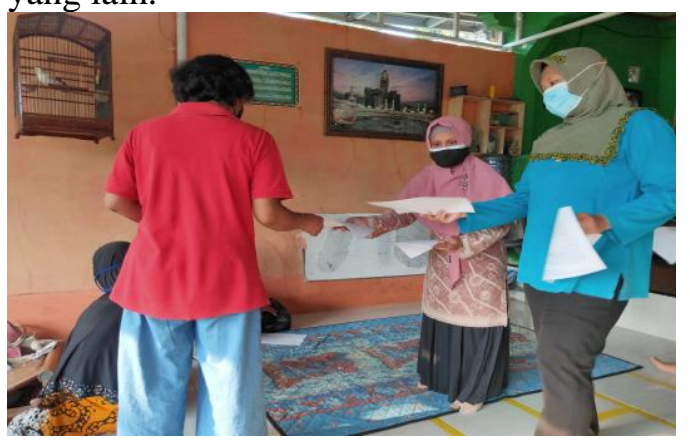

Gambar 1. Pembagian kuisioner 


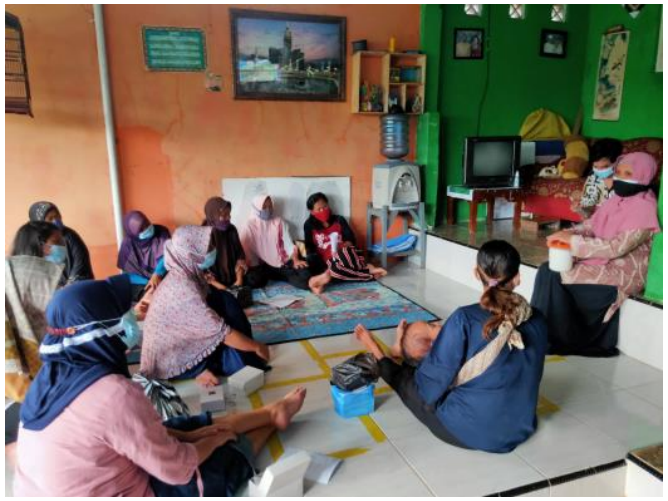

Gambar 2. Sosialisasi manfaat yogurt dan prospek untuk wirausaha

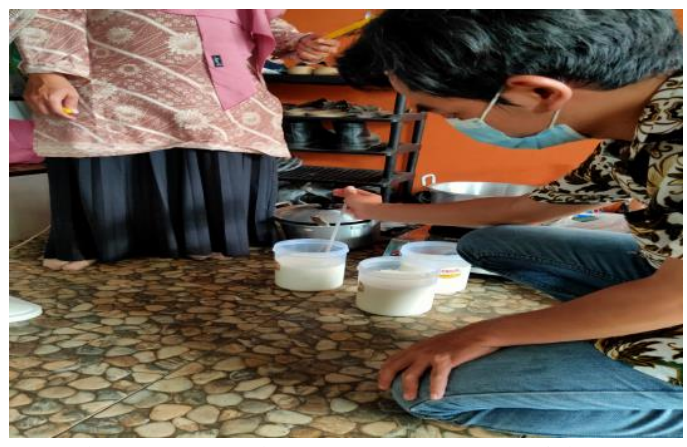

Gambar 3. Pembuatan Yogurt Hari ke-1

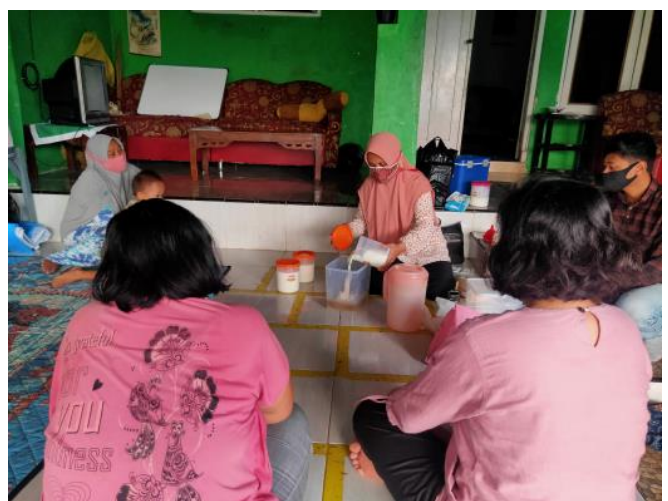

Gambar 4. Pembuatan Yoogurt Hari ke-2

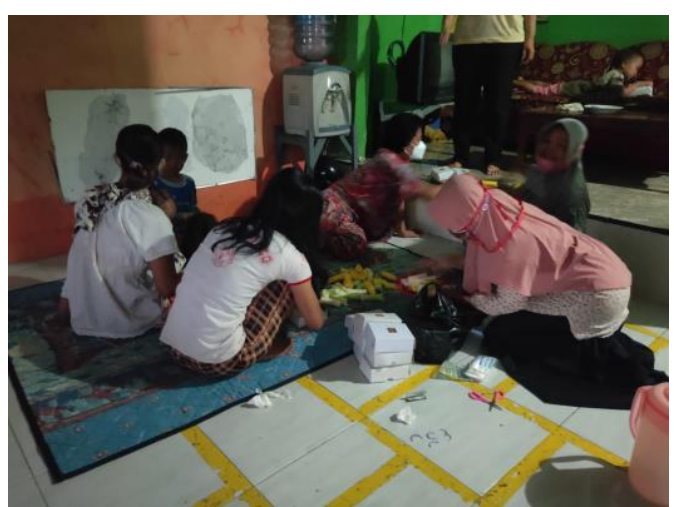

Gambar 5. Pengemasan Yogurt

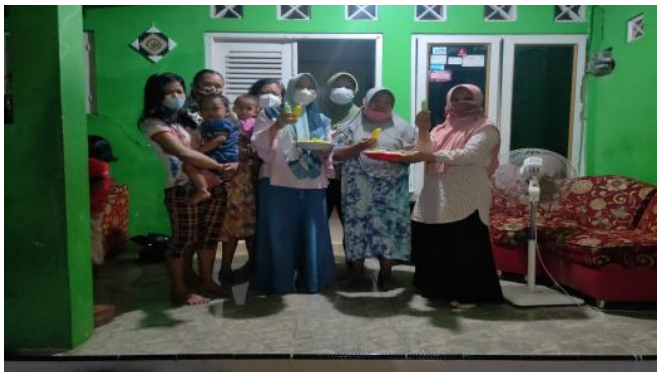

Gambar 6. Yogurt Siap Dikonsumsi

Evaluasi dari kegiatan pengabdian ini dengan memberikan kuisioner setelah kegiatan berakhir. Hasil evaluasi menunjukkan bahwa kegiatan pengabdian ini sangat diharapkan dan dibutuhkan oleh ibu-ibu PKK dalam rangka menambah pengetahuan tentang gizi keluarga, dan keinginan untuk berwirausaha dalam rangka meningkatkan penghasilan apalagi di masa pandemik seperti ini.

Hal ini sesuai target dari kegiatan PKM ini bahwasanya sasaran dari PKM ini adalah ibu-ibu PKK yang mempunyai waktu luang yg banyak, ibuibu yang bekerja non formal yang butuh penghasilan tambahan dan ibu-ibu yang masih mempunyai anak kecil. Kegiatan ini juga memberikan manfaat menambah pengetahuan tentang pentingnya asupan gizi untuk meningkatkan imunitas terutama saat pandemik dengan pembuatan yogurt, serta menumbuhkan keinginan berwirausaha dalam rangka meningkatkan pendapatan keluarga.

\section{Kesimpulan}

Berdasarkan hasil analisis dan evaluasi kegiatan PKM ini, disimpulkan bahwa:

1. Pembuatan yogurt menjadi salah satu tema yang dibutuhkan oleh ibu-ibu PKK dalam rangka menambah pengetahuan mengenai gizi keluarga dan aneka olahan susu yang bernilai fungsional tinggi.

2. Pembuatan yogurt juga memberikan alternatif wacana berwirausaha dalam rangka meningkatkan pendapatan keluarga terutama di masa pandemik. 


\section{Ucapan Terima Kasih}

Penulis mengucapkan terima kasih kepada Universitas Nahdlatul Ulama melalui Lembaga Penelitian dan Pengabdian Masyarakat (LPPM) yang telah memberi dukungan financial terhadap pelaksanaan kegiatan PKM ini.

\section{Daftar Pustaka}

Anindita, N. S., dan D. S. Soyi, 2017. Studi kasus: Pengawasan Kualitas Pangan Hewani melalui Pengujian Kualitas Susu Sapi yang Beredar di Kota Yogyakarta. Jurnal Peternakan Indonesia, Juni 2017, Vol. 19 (2): 96-105.

Candra Sari, A.I., E. Karlina, dan A. Cahyo, 2020. Pemanfaatan Susu Menjadi Olahan Yogurt dan Pemasaran Online Sebagai Sarana untuk Meningkatkan Pendapatan. Jurnal PKM: Pengabdian kepada Masyarakat Vol. 03 No. 02, April-Juni 2020, hal: 136-143.

Mahrus, Abdurrazif, Zulkarnaen, D., Febrianti, W., Rizki, A.N.A., dan Darusman, A., 2021. Pembuatan Abon dari Ikan Tuna Sebagai Salah Satu Alternatif Wirausaha Baru di Desa Batu Nampar Selatan. Jurnal Pengabdian Magister Pendidikan IPA, 2021, 4 (2): 242-245.

DOI:https://doi.org/10.29303/jpmpi.v4i2.824

Wahyuningtyas, D., Hartatik, P. Sulistyowati, dan D., Iswahyudi, 2017. Wirausaha Yogurt dan Stik Susu.

http://repository.unikama.ac.id/id/eprint/1169 